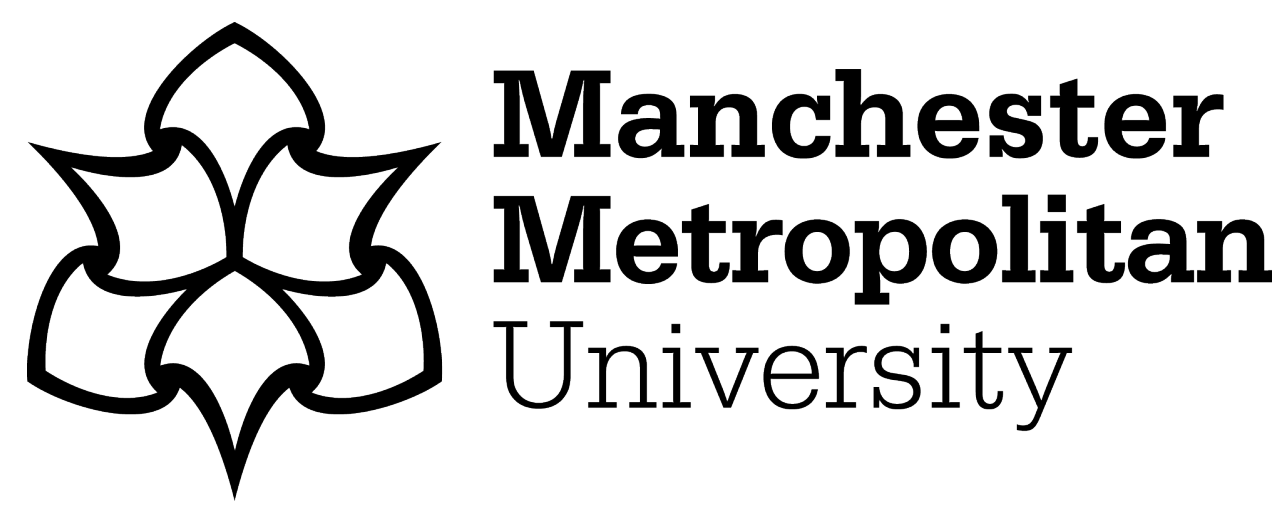

Rose, Mitch, Cooper, David and Griffiths, Hywel (2018) Book Review: Acknowledging the Work of Poetry: A Collaborative Commentary on Tim Cresswell's Fence. Cultural Geographies, 25 (1). pp. 257-262. ISSN 1474-4740

Downloaded from: https://e-space.mmu.ac.uk/623436/

Version: Accepted Version

Publisher: SAGE Publications

DOI: https://doi.org/10.1177/1474474017732982

Please cite the published version 


\title{
Acknowledging the work of poetry: a collaborative commentary on Tim Cresswell's Fence
}

\author{
Mitch Rose \\ Department of Geography and Earth Sciences, Aberystwyth University, UK
}

\section{David Cooper}

Department of English, Manchester Metropolitan University, UK

\section{Hywel Griffiths}

Department of Geography and Earth Sciences, Aberystwyth University, UK

Fence. By Tim Cresswell. London: Penned in the Margins. 2015.72 pp. $£ 9.99$ paperback. ISBN:

9781908058317.

\section{Introduction}

\section{Mitch Rose}

For the philosopher Stanley Cavell, ${ }^{1}$ literature begins where traditional philosophy ends. In his most famous work The Claim of Reason he asks whether it is possible for philosophy to acknowledge that which it cannot know: can philosophy come to be faithful to the unknowable rather than consistently trying to transcend it? Cavell finds salvation in literature because it approaches the esoteric and the mysterious not as things to think ourselves out of but as things to contend with. It approaches unknowabilities as unknowabilities and marks their mystery as the object of investigation.

I am reminded of Cavell whenever I am faced with the ever-increasing emergence of creative work in geography. Here, I am not referring to geographers being creative in their academic practice or to writers being self-consciously geographical. Both of these phenomena have been happening for some time. Rather, I am thinking of geographers becoming novelists, painters and poets ${ }^{2}$ and geographers who have explicitly left academic practice behind (or at least set it aside) to explore geography through a different literary convention. The relevance of Cavell's question applies equally to geography as it does to philosophy. What does creativity do for geography? Where does the literary take geography? Does the geographical novel contend with the mystery of space and time? Does the landscape painting engage with the ineffability of perspective and vision? Does the poem struggle with the esoteric centre of place and home? What does creative work allow that traditional academic practice does not? What does it open that academic practice keeps closed?

While geographers are often willing to speak volumes about why they engage in academic work, they are more hesitant when it comes to their more creative ventures. 'I recently decided to 
become a poet', Tim Cresswell declared in cultural geographies in $2014 .^{3}$ But while that essay charts the history of his training and his various engagements with poets and practitioners along the way, it does not tell us anything about why this decision transpired - why did he decide to become a poet? Perhaps, the only way to answer this is to look at the work itself. To read and comment and think about what this work does and what it does for geography. It is for this reason that we have come together to comment on Tim Cresswell's Fence.

Fence is Cresswell's second book of poetry and, while his first book Soil received accolades in the world of creative writing, it did not generate much response in the discipline of geography. The aim of these reviews is to reflect on the place of Cresswell's poetry and consider what it gives to geography. We want to acknowledge, as Magrane suggests, the work that poetry does for geography. ${ }^{4}$ While this work is the work of performing geographic ideas and themes, to be sure, we suspect that there is more to it than that. As Cavell might suggest, there is also the work of acknowledgement, that is, the work of recognising that the world always surpasses our capacity to measure, map and write it and to contend with the problem that such a recognition leaves us.

\section{The riskiness of the radical}

\section{David Cooper}

In 2011, the poet-critic Harriet Tarlo edited The Ground Aslant: an anthology, published by Shearsman Books, which brings together the work of 16 contemporary landscape poets. The poets and poems selected by Tarlo are, unsurprisingly, a heterogeneous bunch. Yet, despite this diversity, the work of the 16 poets is characterised by what Tarlo terms a 'radical' take on the possibilities of the post-pastoral poem. ${ }^{5}$ For Tarlo, this 'radicalism' is manifest in the collective eschewal of the formal lyric - habitually associated with the poetic mainstream - in favour of 'exploratory and experimental' approaches to the form and shape of the contemporary landscape poem. ${ }^{6}$

The formal 'radicalism' that unifies Tarlo's selection is similarly threaded through Fence: the second volume by Tim Cresswell to be published by the spatially minded 'Penned in the Margins' press and a collection in which the reader is transported to the fragile, edge-of-the-world terrain of the Svalbard Islands. The self-consciously experimental nature of the collection - and its thematic obsession with the marking and claiming of territory - is signalled by the first of its 48 numbered, yet untitled, poems: an opening in which the noun, 'Post', is printed seven times in a parabolic arc across the white space of the page. Over the following pages, Cresswell restlessly plays with a dizzying range of poetic styles, shapes and structures: from the spatial poetics of 'Part $i$ ' to the use of erasure in 'Part xxx'; from the prose poem of 'Part xxii' to the transcription of geographical data in 'Part xxxiii'. It is a bravura performance clearly underpinned by a preoccupation with what Tarlo describes as the 'relationship between the spatial arrangement of the poem and the landscape'.

The reader, then, is taken on a journey to the high Arctic and through a range of poetic possibilities. Crucially, Cresswell also moves the reader backwards and forwards in time as it emerges that the extended sequence consists, in part, of transcriptions and adaptations of earlier textual accounts of this particular place. The accumulative effect - on the first encounter, at least - is one of disorientation: the reader is left slipping over the surfaces of the texts - as the visitor might slide across this uncannily glacial topography - looking for a coherent narrative, or even a stable lyrical 'I', that might help to anchor the 'spatial event' of reading. ${ }^{8}$

Fence, though, is a collection that demands to be re-read, and, upon patient re-reading, a series of concatenated themes and tropes begin to emerge. That is to say, it becomes clear that Cresswell uses poetry to explore geographical issues and concerns which could readily find their way into his academic prose: from the imaginative potency of the far north to the history of whaling; from the 
effects of globalisation to the pervasive presence of borders and boundaries; from the colonial practice of naming to the etymological excavation of landscape terminology. Fence, then, deliberately resists a rigidly linear account of spatial history to offer a neo-Modernist portrayal of the Svalbard Islands as a complicatedly contested, environmentally sensitive and richly (inter)textualised place.

There is a list, facing the title page of Fence, of Cresswell's previous publications, and, saliently, they are divided into 'Poetry' and 'Critical Works'. Here, the creative and the critical are kept apart, but, as Cresswell has acknowledged in his own self-reflexive writings, it is difficult - if not impossible - for the 'geographer/poet' to disentangle the two modes of thinking and the two ways of writing. Ultimately, then, Fence can be read as a timely experiment in the ways creative strategies might lead to the production of geographical knowledge as, through a careful engagement with the detailed particularities of the text, the reader comes to learn more and more about, say, Leonie D'Aunet: 'the first recorded woman in Svalbard', as Cresswell explains in a paratextual note, 'who visited in 1838 ' (p. 72).

The production of this knowledge, however, places not inconsiderable demands on the reader. I am acutely conscious that, in many ways, I - as an academic whose increasingly creative-critical research focuses on literary geographies and who has been reading Fence with at least one eye on contributing to this review - might be considered an untypical reader. As a result, I will leave it to the editors of future anthologies of radical landscape poetry to make qualitative judgements. What I will say, though, is that, for me, there is much to admire in the "risks" ${ }^{\text {' }}$ that Cresswell patently takes in pushing and pulling poetic language and form to think, geographically, about 'this strange corner of the world' (p. 18).

\section{Topography, capital and globalisation}

\section{Hywel Griffiths}

The stark and unfamiliar landscape and topography of Svalbard in the high Arctic are, as one would expect, skilfully placed upon the page in Tim Cresswell's second collection. In part, this is a result of expert use of imagery and metaphor, but also of the way Cresswell draws out layers of history and culture imbued within rock and ice through interweaving poems inspired by archive material. The naming of places and the marking of territory at various stages in its history contribute to the framing of Svalbard's fragile landscape as dynamic and shifting.

One of the foremost Welsh nature poets, Robert Williams Parry, once wrote 'Nes na'r hanesydd at y gwir di-goll/Ydyw'r dramodydd, sydd yn gelwydd oll' (Nearer to the absolute truth than the historian/ is the dramatist, who is all lies). ${ }^{10}$ Cresswell's attempt to find a creative truth from historical archive sources is, on the whole, a successful experiment. In the majority of cases, Cresswell finds and enhances their inherent poetry and drama. An intimacy which a reader might feel is lacking in the 'present-day' poems, arguably unavoidable given the nature of the place, is drawn out in these historical poems, particularly in his sympathetic portraits of Leonie D'Aunet.

There is playfulness with form, style and language which I found refreshing. 'Part xvi' and 'Part xvii', for example, explore the proverbial potential of 'fence' ('love your neighbour but keep your fence' - p. 28) and its etymology ('in the $15^{\text {th }}$ century fence/ became a thing' - p. 29), respectively. 'Part xxiii' in which Cresswell subverts (and arguably corrects) text from cruise handbooks for Svalbard using erasure and the hourglass-shaped concrete poem 'Part xliv' are further evidence of the confidence with which Cresswell experiments in this collection.

If the form, style and tone of the poems vary, then so do the geographical themes that are explored. Three themes struck me as being particularly powerful. The first of these is the evocation 
of topography which is not only found in the descriptions of Svalbard but also in other, more unexpected places, such as his imagining of a woman being fitted with a corset made of baleen:

\author{
anatomy as topography \\ contours moulded \\ vistas like Capability Brown \\ rippled ribs painted nipples \\ drumlins valleys \\ moraines kettle holes. (p. 63)
}

The collaboration between poet Alyson Hallet and physical geographer Chris Caseldine, Six Days in Iceland, similarly explore the lyrical potential of topographical and geomorphological terms and it is clear that there is potential for geographer-poets to explore this further. ${ }^{11}$

Second, I was struck by the portrayal of the Artic as a place which creates and confounds capital. The destination of whalers looking for blubber and baleen - where they targeted "the "right" whales to kill/ swam slowly/ surfaced regularly/ floated when dead ...' (p. 48) - is also the place where there is no mobile phone signal. It is also the place which ultimately, as described so hauntingly in 'Part xlvi', towards the end of the collection, consumes the whaling ship by trapping it in freezing ice, stranding the whalers and leaving them at the mercy of the cold, hunger and bears. Also, today, in 'Part ix', the poet and his fellow travellers are clad in 'neoprene merino wool/ hiperformance fleece breathable shells' (p. 20) but the iPhone is switched off.

Third, I particularly enjoyed the collection's progression towards the inevitability of globalisation and the sense of dark foreboding which is introduced along the journey. In 'Part xv', a list of names ('Red Cliff Sound./ Red Beach./ Redbeach Point') ends abruptly with 'Point Deceit' (p. 27), and in 'Part xi', we have the history of the naming of Magdalenwfjorden throughout history ending with 'Gravneset/ which means 'grave site”' (p. 22). In 'Part xviv', D'Aunet hears the sailors talking about her - 'Assuming the ice takes us she will/ be first to die' - p. 32), and in another poem ('Part xxxvii') there is dramatic irony in naming - 'the Captain named the peninsular/ Tombeaux (Grave site)' (p. 54). The human sacrifice and the exploitation of nature lead to a kind of denouement in 'Part xlviii', where Cresswell sees the 'whale-fuelled' 'metropolis', the lit room of the 'late-night writer', the 'night-trains' and the 'CCTV/ 24/7 economy' (p. 70). This feels like the poem which would be most effective in a performance - appropriately fast-paced, staccato lines with internal rhyming, calling forth images of rushing traffic in a busy city, far, far away from the stark Arctic 'where the Blowheads lived' (p. 70) and where Cresswell began simply with seven posts in a semi-circle.

\title{
A broken landscape and an elusive poet
}

\section{Mitch Rose}

When Tim Cresswell's debut book of poetry Soil was published in 2013, it was a revelation to me. While geographers had been exhorting each other to be more experimental and creative in their conception, approach and execution of geography, it was difficult for many of us to see what actual creative geographies might look like. Yes, there were some examples of innovative geographic writing, but a lot of it was bad and clearly lacking in the training needed to execute themes in a distinctively creative voice. In this context, Soil laid down a marker for what creative geographies 
could do. Clearly born of years of writing and workshopping, it was first and foremost good poetry. Even as it touched upon geographic themes, there were surely more geographical poets out there (e.g. Elizabeth Bishop, Alice Oswald, Barry MacSweeny), and while many colleagues celebrated the collection's geographical eye, I felt that the poems explicitly referencing the discipline (e.g. 'Human geography', 'Landscape') were the least successful.

It is for this reason that I approached Fence with some apprehension. Given its obvious geographical topic (Svalbard), I anticipated more intellectualism and an even more intensive appropriation of disciplinary concepts. I was right and wrong about this. Fence is a doubling-down on geography, but in Cresswell's second collection, he finds his feet and delivers a poetic narrative that is far more coherent, far more thoughtful and far more curious than anything we find in Soil. While the themes are explicitly geographic, the concepts are distanced and the imagery and voice are moved to the front. The landscape of Svalbard is powerful and broken. The spacing between the words echo the disconnections it foists on its travellers and the various ways they endeavour to mark this landscape in their own language. While names and posts proliferate the frozen earth, they are strewn and shattered, creaking like a harpoon bending between wave, whale and a cold sailor's hands. The result is intellectually satisfying and rich and while the concepts it plays with are reminiscent of things we find in geography, they feel more aligned to the work of Tim Robinson, Jonathan Raban and Robert Macfarlane than to Serres or Latour. And far better because of it.

Yet, with this all said, I cannot help but be somewhat disappointed by Fence. One of the difficulties I found with Soil was its distance and elusiveness. An example can be seen in the final of poem of Soil where the poet wonders at his partner's post-coital tears: 'she sinks to sleep', he writes, 'leaving me/ alone with the digital/ green alarm glow and sodium/ orange through the gaps around/ the velux blinds. A late jumbo/ throttles up and noses over Harlesden'. ${ }^{12}$ It is a scene of great poignancy but frustrating distance (the theme of planes hovering overhead pervades the collection). Personal and yet defensively aloof. Perhaps, it was too much to expect some connection, some warmth, from a collection about isolation and the cracking shoulders of ice and rock. Stranded on its barren shore, I found myself curious and intrigued by the detritus, but also craving something human, maybe something intimate. To be disrupted in such a manner is no doubt a testament to Cresswell's skill and should cement his reputation as a powerful and effective evoker of place. But part of me can't help wishing his next collection will be less geographical.

\section{Notes}

1. S.Cavell, The Claim of Reason: Wittgenstein, Skepticism, Morality, and Tragedy (Oxford: Oxford University Press, 1999).

2. See T.Cresswell, Soil (London: Penned in the Margins, 2013); S.De Leeuw, Geographies of a Lover (Edmonton: NeWest Press, 2012); H.Griffiths, Llif Coch Awst (Tal-y-bont: Barddas, 2017); R.Kitchin, The White Gallows (Brighton: Indepenpress, 2010).

3. T.Cresswell, 'Geographies of Poetry/Poetries of Geography', cultural geographies, 21(1), 2014, pp. $141-6$.

4. E.Magrane, 'Situating Geopoetics', GeoHumanities, 1, 2015, pp. 86-102.

5. H.Tarlo, The Ground Aslant: An Anthology of Radical Landscape Poetry (Exeter: Shearsman Books, 2011).

6. Tarlo, 'Introduction', The Ground Aslant, p. 8.

7. Tarlo, 'Introduction', The Ground Aslant, p. 9.

8. S.Hones, 'Literary Geography: The Novel as a Spatial Event', in S.Daniels, D.DeLyser, J.N.Entrikin and D.Richardson (eds), Envisioning Landscapes, Making Worlds: Geography and the Humanities (London: Routledge, 2011), pp. 247-55.

9. On these 'risks', see Cresswell, 'Geographies of Poetry/Poetry of Geographies', p. 144.

10. R.Parry, 'Gwae Awdur Dyddiaduron' in Cerddi'r Gaeaf (Denbigh: Gwasg Gee, 1952), p. 66. 
11. S.Hallett and C.Caseldine, Six Days in Iceland (Stoke Gabriel: Dropstone Press, 2011).

12. Cresswell, Soil, p. 79.

\section{Author biographies}

Mitch Rose is a senior lecturer in Cultural Geography at Aberystwyth University.

David Cooper is a senior lecturer in English at Manchester Metropolitan University and co-editor of Poetry \& Geography (Liverpool University Press).

Hywel Griffiths is a senior lecturer in Geography at Aberystwyth University and prifardd ('chief poet' of the National Eisteddfod of Wales). 